Piotr Chomczyński

Instytut Socjologii UŁ

\title{
¡Viva la Revolución! \\ Rewolucja kubańska 1956-1959 i jej konsekwencje w rzeczywistości zimnowojennej Socjologiczna analiza plakatów kubańskich
}

\section{Wstęp}

W historii powszechnej nie brak momentów przełomowych, które, ze względu na splot różnego rodzaju uwarunkowań, prowadziły do rozstrzygnięć mających poważne konsekwencje historyczne i geopolityczne. Wydarzenia tego typu obejmowały swoim zasięgiem całe pokolenia, przekraczając granice krajów, a nawet kontynentów. Do tego rodzaju epizodów z pewnością należy rewolucja kubańska z lat 1956-1959, która wyniosła Fidela Castro i jego towarzyszy na szczyty władzy na Kubie. Przebieg samego przewrotu jako takiego nie odbiega zbytnio od wielu wcześniejszych i późniejszych scenariuszy, pojawiających się pod każdą szerokością geograficzną. Tym, co czyni go wyjątkowo ważnym jest kontekst geopolityczny, w jakim się odbył, a także konsekwencje wagi światowej, jakie wywołał. Sama rewolucja odbyła się w zimnowojennej rzeczywistości, która przypominała cienki lód pokrywający wartki strumień. Każde, nawet błahe, wydarzenie na zasadzie domina mogło pociągnąć za sobą spiralę zbrojnych reakcji wiodących ku III wojnie światowej, w której centralną strategią miał być szybki atak atomowy na pozycje przeciwnika. Następujące po rewolucji i bezpośrednio z nią związane wydarzenia, takie jak inwazja w Zatoce Świń (1961) czy kryzys kubański (1962) wiodły świat 
na skraj atomowej zagłady. Każdy z tych momentów był przełomowy, a w związku z tym wart głębszej refleksji. W tym jednak przypadku postanowiłem skupić uwagę na rewolucji kubańskiej, jednoczącej działania sił wewnętrznych, a także Stanów Zjednoczonych, inicjujące dalsze wydarzenia, związane z niewielkim terytorialnie państwem regionu Morza Karaibskiego, z pozoru nie mającym wielkiego znaczenia dla światowego establishmentu.

Niniejsza praca obejmuje rezultaty analizy treści plakatów przedstawiających rewolucję na Kubie, a także jej dalsze konsekwencje. Z racji jej międzynarodowego charakteru i rezultatów, jakie za sobą pociągnęła, badaniami objęte zostały plakaty wydane na Kubie, a także przez różne organizacje pozarządowe wspierające Kubę w jej walce o utrzymanie zdobyczy rewolucyjnych. W szczególności mam tutaj na myśli OSPAAAL (Organization in Solidarity with the People of Africa, Asia, and Latin America - Organizację na Rzecz Solidarności z Ludnością Afryki, Azji i Ameryki Łacińskiej). Ponadto, ze względu na fakt, że w czasie trwania samej rewolucji powstała relatywnie niewielka liczba plakatów w porównaniu z okresem późniejszym, analizie poddano postery, których emisja przypada na kolejne lata. Zanim jednak zaprezentowane zostaną wyniki badań, przedstawię w kilku słowach kontekst historyczny rewolucji kubańskiej, który jest niezbędny dla zrozumienia motywów widocznych na plakatach. W dalszej kolejności przybliżona zostanie metodologia badań.

\section{Tło historyczne i społeczne rewolucji kubańskiej}

Rewolucja kubańska, choć datowana na okres 1956-1959, miała swoje nieudane początki parę lat wcześniej, gdy 26 lipca $^{1} 1953$ r. 165-osobowy oddział rebeliantów ${ }^{2}$, z Fidelem Castro i jego bratem Raulem na cze-

${ }^{1}$ Od tego czasu 26 lipca to Dzień Powstania Narodowego.

${ }^{2}$ Dokładna liczba atakujących nie jest znana, choć ta podawana jest najczęściej. Andrzej Bińkowski (1981, bez strony), powołując się na wspomnienia Raula Castro opublikowane w 1961 r. na łamach miesięcznika „Fundamentos” stwierdza, że „było ich 168, jednakże z analizy przemówienia Fidela Castro wygłoszonego 16 października 1953 r. przed sądem doraźnym w Santiago można wywnioskować, że było ich nie więcej niż 150, prawdopodobnie 148 - tę ostatnią liczbę potwierdzają również wyliczenia przeprowadzone przez historyka Hugha Thomasa". 
le, zaatakował koszary Moncada w Santiago de Cuba na południowym wschodzie kraju. Atak został odparty, Fidel i Raul schwytani i w wyniku procesu skazani odpowiednio na 15 i 13 lat więzienia, wielu zaś innych rebeliantów poniosło śmierć w walce lub zostało schwytanych i zgładzonych. Nieudane zbrojne wystąpienie przeciwko dyktaturze generała Flugencio Batisty, który od roku 1933 nieformalnie, od roku 1940 natomiast jako prezydent, sprawował władzę w kraju ${ }^{3}$, było jednym $\mathrm{z}$ wielu mniej lub bardziej zdecydowanych aktów protestów wybuchających w całym kraju. Warto wspomnieć, że Batiście przypisywano odpowiedzialność za liczne ofiary śmiertelne wśród opozycjonistów. Reporter Hal Hendrix z „Miami News” w reportażu z 18 stycznia 1959 r. donosił, że „ocenia się, że 20000 mężczyzn, kobiet i dzieci zostało zabitych przez reżim Batisty w ciągu ostatnich 7 lat” („Miami News”, 18.01.1959). Biorąc pod uwagę te fakty i kontekst geopolityczny Fidel Castro mógł w czasie rewolucji i bezpośrednio po jej zakończeniu liczyć, jeśli nie na wsparcie, to z pewnością na zrozumienie wśród wielu liderów opinii publicznej, w tym ówczesnego prezydenta Stanów Zjednoczonych, Johna F. Kennedy'ego. W wywiadzie udzielonym 24 października 1963 r., więc po kryzysie kubańskim, amerykański prezydent, retrospektywnie wypowiedział poniższe słowa, tłumacząc okoliczności rewolucji kubańskiej:

Wierzę, że nie ma innego kraju na świecie, wliczając wszystkie razem wzięte kraje objęte kolonialną dominacją gdzie ekonomiczna kolonizacja, poniżenie i wyzysk byłby silniejsze niż na Kubie, po części z winy polityki mojego kraju wobec reżimu Batisty. Zaakceptowałem proklamację złożoną przez Fidela Castro w Sierra Maestra, kiedy zasłużenie wołał o sprawiedliwość, szczególnie pragnąc oczyszczenia Kuby z korupcji. Pójdę nawet o krok dalej: do pewnego stopnia Batista był ucieleśnieniem grzechów leżących po stronie Stanów Zjednoczonych. Teraz musimy za nie zapłacić. W kwestii reżimu Batisty zgadzam się z pierwszymi kubańskimi rewolucjonistami. To jest całkowicie jasne.

Słowa Kennedy'ego opisują zapaść ekonomiczną i społeczną kraju, którego reżim od lat wspierany był przez rząd Stanów Zjednoczonych. Stany w świadomości obywateli Kuby, jak również samych przywódców rebelii, jawiły się jako państwo wrogie, które z pomocą szeroko rozwiniętej korupcji utrzymuje na wyspie status quo. Pauperyzacja społeczeństwa i bieda stale pogłębiały przepaść pomiędzy władzą a obywatelami. Fakt ten odegrał później istotną rolę w relacjach nowego kubańskiego aparatu

${ }^{3}$ W roku 1944, po upływie kadencji, Batista został zmuszony do opuszczenia kraju emigrując na Florydę w Stanach Zjednoczonych. Na Kubę powrócił w roku 1952, w efekcie przewrotu odsuwając od władzy ówczesnego prezydenta Carlosa Prío Socarrása. 
władzy i kolejnych włodarzy Białego Domu, jak również ich administracji (por. Bińkowski 1981). Nawet podjęta przez prezydenta Dwighta Eisenhowera w marcu roku 1958 decyzja o wstrzymaniu dostaw broni dla Batisty, która przyczyniła się do wygranej Castro, nie stanowiła pewnego gruntu dla budowania dobrych relacji w przyszłości ${ }^{4}$.

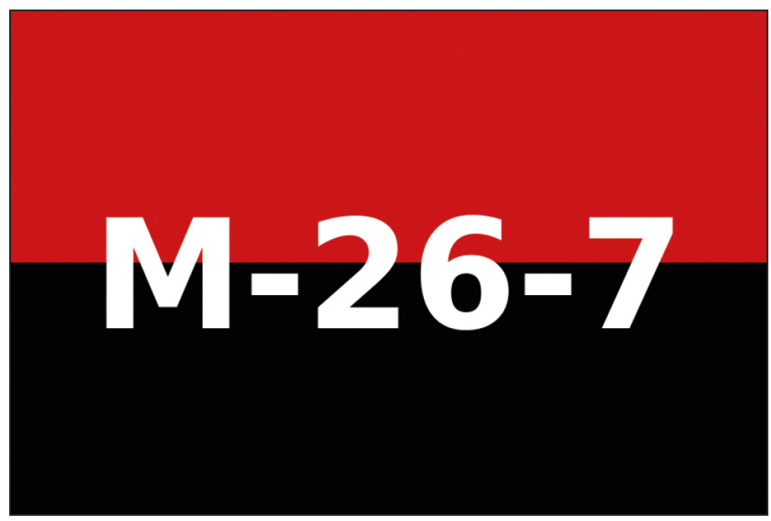

Rycina 1. Flaga Ruchu 26 lipca

Wracając do spraw wewnętrznych Kuby, 15 maja 1955 r. (Luis 2008: 3), więc w dwa lata po nieudanym ataku, Fidel i Raul na skutek nacisków zagranicznej opinii publicznej zostali zwolnieni z więzienia i udali się na przymusową emigrację do Meksyku, gdzie spotkali Ernesto "Che" Guevarę, wraz z którym założyli szybko rosnący w siłę ruch 26 lipca (patrz rycina 1), który symbolizował opór wobec skorumpowanego reżimu Batisty. Kontakt z argentyńskim rewolucjonistą Che Guevara, posiadającym bogate doświadczenie militarne, charyzmę i zaangażowanym w sprawę (por. Gadea 2008) zaowocował organizacją kolejnej misji, której początek przypada na 2 grudnia $1956 \mathrm{r}$. Także i tym razem liczący około 80 osób (Bińkowski 1981) oddział został pokonany, ocaleli rebelianci schronili się zaś w górach Sierra Maestra. W odróżnieniu od wydarzeń lipcowych z roku 1953 wypadki potoczyły się jednak bardziej dla nich pomyślnie. Przez trzy lata zwolenników rewolucji znacznie przybyło, liczba ich sięgała teraz kilkuset osób. Przez ten czas ze zmiennym dla każdej ze stron szczęściem trwały walki, w wyniku których z początkiem roku 1959, po ucieczce Batisty, rewolucjoniści zajęli stolicę kraju Hawanę przystępując do budowania rządu oraz wprowadzania

${ }^{4}$ Źródło: http://www.stosunkimiedzynarodowe.info/kraj_start.php?xkraj_stos=USA\& kraj=Kuba\&typ=stosunki+dwustronne (dostęp z dnia: 15 X 2012). 
reform. Obok Fidela Castro i jego brata Raula symbolicznym „ojcem” rewolucji stał się Ernesto „Che” Guevara, zyskując na zawsze miano kubańskiego bohatera narodowego ${ }^{5}$.

W październiku roku 1959, gdy Stany Zjednoczone zyskały pewność co do komunistycznych inklinacji nowych władz Kuby, Eisenhower aprobował plan pozbycia się Castro za pomocą CIA (Central Inteligency Agency), czego konsekwencją była seria nieudanych zamachów na życie przywódcy Kuby, kulminacją zaś przeprowadzona 17 kwietnia 1961 r., nieudana i dyskredytująca USA, inwazja w Zatoce Świń. Od tego momentu „oficjalnym" wrogiem Kuby stał się jej północny sąsiad. Kolejnym punktem kulminacyjnym stosunków kubańsko-północnoamerykańskich, lecz o wymiarze globalnym, było rozmieszczenie rakiet radzieckich na terytorium Kuby, dostrzeżone przez USA w sierpniu roku 1962. Choć konflikt został zażegnany bez użycia środków ostatecznych, doradzanych przez otoczenie prezydenta Johna F. Kennedy'ego (Pastusiak 2007: 358-359) Biały Dom zdał sobie sprawę z faktu, że Kuba na trwałe znalazła się w sferze wpływów ZSRR. Z perspektywy czasu Walter Lippmann w kilku słowach wypowiedział komentarz do tych wydarzeń:

Z zasady nigdy nie powinniśmy niczego robić dla współpracy z rewolucyjnymi państwami, w które świat obfituje, źle także jest popychać je za żelazną kurtynę, którą same wznoszą. Z drugiej strony, nawet jeśli zostały skuszone i przekroczyły linię, właściwą rzeczą jest pozostawić im drogę powrotną (tłum. własne).

Słowa te oddają przekonania części polityków i amerykańskiej opinii publicznej na temat polityki zagranicznej Stanów Zjednoczonych wobec Kuby, a także innych państw latynoskich. Wątek prowadzenia mniej lub bardziej oficjalnych operacji militarnych w regionie Ameryki Łacińskiej, a także Azji znalazł odzwierciedlenie na licznych plakatach, które z jednej strony podnosiły sprawę agresywnej polityki USA wobec innych (słabszych) państw, z drugiej zaś apelowały do „międzynarodowej solidarności” wymierzonej w północnoamerykańskiego agresora. Można uznać, że te dwie kategorie pozostają wobec siebie w relacji przyczynowo-skutkowej.

${ }^{5}$ Do chwili obecnej kult "Che" jest bardzo rozpowszechniony nie tylko w Ameryce Południowej (pomniki w Santa Clara na Kubie czy w La Higuera w Boliwii, gdzie "Che" został stracony w roku 1967), lecz także w innych krajach, w tym europejskich (popiersie Che Guevary w Wiedniu). Dochodzą do tego niezliczone nadruki na T-shirtach sprzedawanych na całym świecie.

${ }^{6}$ Lewicowe nastawienie przywódców Kuby zyskuje potwierdzenie w lutowej wizycie (1960) radzieckiego ministra spraw zagranicznych Anastasa Mikoyana.

7 Źródło: http://www.historyofcuba.com/history/time/timetbl4.htm (dostęp z dnia $17 \times 2012)$. 
Warto tu także $\mathrm{w}$ paru słowach przedstawić kubańską propagandę i jej narzędzia. W zasadzie na Kubie istnieje kilka znaczniejszych ośrodków informacyjnych, które odpowiadają za większość propagandy, także i w dzisiejszych czasach stale obecnej w życiu codziennym (patrz plakat 1). Wśród tych najważniejszych wymienić należy Editora Politica (Wydawca Kubańskiej Partii Komunistyczneje), ICAIC (Kubański Instytut Filmowy) oraz OSPAAAL (Organizację na Rzecz Solidarności z Ludnością Afryki, Azji i Ameryki Łacińskiej). W przypadku posterów najbardziej znacząca jest międzynarodowa organizacja OSPAAAL z siedzibą w Hawanie, która jednoczy

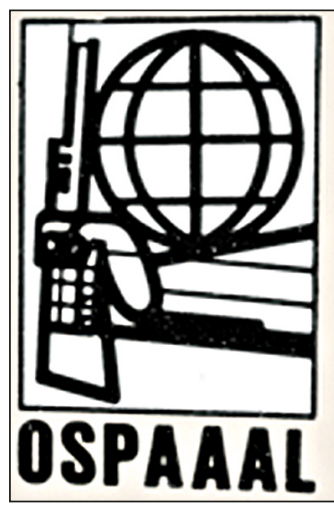

Rysunek 1 artystów z całego świata. Ich twórczość stanowi „tubę" interesów kubańskich, wedle których Kuba jawi się jako samozwańczy obrońca i protektor innych krajów, które doznały krzywd ze strony Stanów Zjednoczonych i kapitalizmu. W niniejszej pracy większość analizowanych posterów jest autorstwa plakacistów pracujących dla OSPAAAL. Są one oznaczone symbolem organizacji (rysunek 1) podkreślającym międzynarodowy charakter walki o „sprawiedliwość".

\section{Metodologia analizy plakatów wojennych ${ }^{9}$}

W ostatnich czasach dużo napisano na temat metodologii badań związanych z szeroko pojętym obrazem, ukazało się również wiele publikacji empirycznych tworzonych na bazie materiałów wizualnych. Różnorodność prowadzonych badań odzwierciedla w pewnym stopniu wielość stosowanych metodologii. Brak jednoznaczności w tym obszarze socjologii i relatywizacja tej kwestii wynikają z samej natury obrazu, który ze wzglę-

${ }^{8}$ Więcej informacji na temat propagandy i jej historii na Kubie odnaleźć można w zapisie wywiadu z Félixem Beltránem (http://www.cuban-posters.freeservers.com/beltran. html, dostęp z dnia 02 II 2013).

${ }^{9}$ Ze względu na fakt, że sposób gromadzenia i analizowania plakatów wojennych pozostał niezmienny, niniejszy fragment metodologiczny pochodzi z napisanego przeze mnie rozdziału "Wielka wojna ojczyźniana" na plakatach sowieckich, [w:] Socjologia wizualna $w$ praktyce. Plakat jako narzędzie propagandy wojennej, red. T. Ferenc, W. Dymarczyk, P. Chomczyński, Wydawnictwo Uniwersytetu Łódzkiego, Łódź (2011). 
du na swą specyfikę stwarza znaczny margines interpretacyjny. Gary C. Stańczak stwierdza, że „obrazy będą wywoływać różne skojarzenia zależnie od różnych pytań, jakie im zadajemy" (Stańczak 2007: 9) w zakresie stosowanych metod badawczych. Badacze, niejednokrotnie stojąc przed problemem interpretacji treści materiału wizualnego, w przypadku zdjęć wspomagają się interpretacjami dokonywanymi przez samych ich autorów (patrz Konecki 2005) lub też zadają pytania rozmówcom, którzy nie są autorami fotografii, lecz artykułują własne sądy na temat obrazu (Frąckowiak 2008).

W niniejszym artykule podstawą analizy są materiały wizualne szczególnego charakteru, mianowicie plakaty. Wyznaczają one zakres możliwych metodologii, jak również technik, które mogą być wykorzystane. W tym przypadku zdecydowałem się na indukcyjny model budowania kategorii analitycznych, służących opisowi treści plakatów, stanowiących materiał zastany (Konecki 2005: 47). Jest to sposób nieco odmienny niż na przykład zaproponowany przez Gillian Rose, a wykorzystany w książce Socjologia wizualna w praktyce. Plakat jako narzędzie propagandy wojennej przez Tomasza Ferenca $\mathrm{w}$ analizie plakatów amerykańskich. Autorka proponuje wygenerowanie zbioru kategorii służących analizie materiału empirycznego. Kategorie te muszą służyć do opisu wszystkich elementów zbioru (plakatów), powinny być wyczerpujące, czyli uwzględniać wszystkie aspekty zgromadzonego materiału, winny być też rozdzielne i pomocne w analizie wizualnej (Rose 2006: 56-60, także Ferenc 2007).

W podjętej analizie postanowiłem wybrać inną drogę, gdyż mój materiał badawczy stanowiła grupa plakatów kubańskich (przedstawiających rewolucję kubańską i okres stabilizacji nowej władzy), w związku z tym nie dokonywałem porównań opartych na wcześniej wyodrębnionych kategoriach.

Wykonana przeze mnie analiza plakatów dzieliła się na kilka etapów. W procesie gromadzenia bazy posterów korzystałem ze zbiorów umieszczonych w Internecie. Plakatów szukałem wśród prywatnych kolekcji, a także $w$ tych należących do organizacji pozarządowych (np. OSPAAAL), instytucji państwowych (np. muzea) i na innych stronach tematycznych poświęconych plakatom przedstawiającym rewolucję kubańską oraz inne wątki związane z rządami Castro i jego poglądy na światowy establishment. Poszukiwania na początku obejmowały zarówno te postery, których treści byłyby apologetyczne wobec rewolucji, jak i przedstawiające ją $\mathrm{w}$ niekorzystnym świetle, choć tych ostatnich $\mathrm{w}$ zasadzie nie udało mi się odnaleźć. Szczególnie przydatne okazały się strony inter- 
netowe http://www.docspopuli.org/, http://cuban1.sweb.cz, http://www. iisg.nl, na których umieszczono plakaty zawierające najwięcej informacji (data emisji, nazwisko autora, tytuł). W celu weryfikacji danych zawartych na stronie (autor, data emisji itd.), jak również poszerzenia bazy zgromadzonych przeze mnie plakatów odwiedziłem także inne strony zawierające opisy i analizę plakatów, m.in. http://freyafaulkner.blogspot.com/.

Kolejnym etapem było dokonanie kategoryzacji zgromadzonych obrazów. Postanowiłem tu wykorzystać indukcyjny schemat analizy, który polegał na przeanalizowaniu wszystkich zgromadzonych przeze mnie plakatów (64 sztuki) i zastosowaniu kodowania otwartego (patrz Strauss, Corbin 1990: 65), którym objąłem zarówno obraz, jak i jego opis (tytuł plakatu, zdania, sentencje, hasła itd., stanowiące jego integralną część). Dzięki temu zwiększyłem prawdopodobieństwo poprawnego odczytania warstwy znaczeniowej posteru, opierającej się na nierozerwalnej relacji tekstu i obrazu. W rezultacie kodowania otwartego wyodrębniłem etykiety, które następnie pozwoliły mi utworzyć kategorie. W dalszej części pracy rozpocząłem proces kodowania selektywnego (por. Strauss, Corbin 1990: 116142) kolejnych obrazów, celem nasycenia wcześniej wyodrębnionych kategorii. Gdy analizowane plakaty nie wzbogacały już własności kategorii, uznałem, że uzyskałem zadowalający poziom ich teoretycznego nasycenia. Później ponownie przeanalizowałem wszystkie zgromadzone plakaty dobierając do egzemplifikacji kategorii jedynie te, które w najbardziej wyraźny sposób je obrazowały. W analizach i kodowaniu pomocny okazał się program komputerowy Atlas TI (por. Chomczyński 2012; Konopasek 2008) dający możliwość efektywnej analizy i konceptualizacji w zakresie tworzenia taksonomii. Budując kategorie, jak już wspomniałem, oparłem się na warstwie semantycznej plakatu, lecz także wziąłem pod uwagę cel, jakiemu miał on służyć. Niektóre plakaty, ze względu na charakteryzujący je eklektyzm znaczeniowy, obrazowały więcej niż jedną kategorię, więc przypisanie ich tylko do jednej z nich miało charakter arbitralny. Ponadto mam świadomość, że wyodrębnione przeze mnie kategorie, z racji ograniczonej liczby dostępnych plakatów, nie wyczerpują wszystkich możliwości, a sygnalizują jedynie główne wątki widoczne na plakatach odnoszących się do rewolucji kubańskiej i do okresu stabilizacji nowej władzy.

W tym miejscu chciałbym przybliżyć wyodrębnione kategorie analityczne i w paru słowach dokonać ich charakterystyki:

1. Rewolucja kubańska i jej bohaterowie. Ta kategoria obejmuje plakaty, które odnoszą się do wydarzeń bezpośrednio związanych z przebiegiem działań rewolucyjnych. Na posterach widoczne są czołowe postaci 
stanowiące symbol oporu wobec rządu Batisty, które wzięły na siebie rolę przywódców rewolucyjnych. Są oni przedstawieni w charakterze mężów opatrznościowych, którzy zmienili bieg historii, na trwałe wpisując się w kolektywną pamięć Kubańczyków.

2. Armia rewolucyjna. $W$ ramach tej grupy plakatów dominują dwa główne motywy, za pomocą których przedstawiane są oddziały rewolucyjne, a także armia kubańska jako taka, już po zakończeniu konfliktu zbrojnego. Z jednej strony plakaciści kładą nacisk na profesjonalne i militarne walory wojska kubańskiego, z drugiej zaś przekonują widza o jego ludzkiej (niewinnej) twarzy.

3. Stany Zjednoczone jako pokonany wróg. Choć Kuba i Stany Zjednoczone nigdy nie prowadziły ze sobą otwartej wojny, to jednak fakt wieloletniego wspierania przez Amerykanów rządu generała Batisty, a także późniejsza próba obalenia ekipy Fidela Castro (atak w Zatoce Świń) ukształtowały sposób, w jaki kubańska propaganda przedstawiała północnoamerykańskiego sąsiada. Uwypukleniu ulegają tutaj odniesienia do symboliki Stanów, których agresywna polityka zderzyła się z kubańskim oporem.

4. Polityka zagraniczna Stanów Zjednoczonych. Wysiłki propagandy kubańskiej skoncentrowane były na ukazaniu Stanów Zjednoczonych jako agresywnego mocarstwa, które, posiadając interesy w rozlicznych miejscach na świecie, ingeruje w politykę wewnętrzną innych państw, posuwając się nawet do interwencji zbrojnych. Plakaty należące do tej grupy obrazują amerykańską agresję w Nikaragui, Panamie, Libanie, Palestynie, Wietnamie, Korei i innych miejscach, gdzie Biały Dom był zaangażowany po którejś ze stron konfliktów. Przekaz w tym przypadku jest jasny: Kuba (przedstawiana często jako małe tery torialnie państwo) stanowi ofiarę mocarstwowych ambicji swego potężnego północnego sąsiada.

5. Międzynarodowa solidarność przeciwko Stanom Zjednoczonym. Ta kategoria zawiera postery, które apelują do antyamerykańskiej solidarności (koalicji) w gronie państw (kontynentów), doświadczających ingerencji (agresji) ze strony Stanów Zjednoczonych. Wydawcą tej grupy plakatów jest wspomniana międzynarodowa organizacja OSPAAAL, mająca swą siedzibę na Hawanie.

6. Kapitalizm i zagrożenia z nim związane. Wraz ze zmianą rządów na Kubie zmienił się także system ustrojowy, który na skutek konstelacji różnego rodzaju wydarzeń polityczno-militarnych (inwazja w Zatoce Swiń, kryzys kubański) obrał kierunek socjalistycznego modelu gospodarki, co wyznaczyło także naturalne sojusze (Rosja Radziecka i państwa sa- 
telickie) i wrogów (Stany Zjednoczone, państwa zachodnie). Nowy ustrój w sposób automatyczny stanął w opozycji wobec kapitalizmu ucieleśnianego przez Stany Zjednoczone.

\section{Rewolucja kubańska i jej bohaterowie}

Po dziś dzień kubańskie ulice, miejsca użyteczności publicznej, szkoły, urzędy i inne miejsca "przyozdobione" są symbolami przypominającymi wydarzenia sprzed przeszło pół wieku, czyli walki rewolucyjne i objęcie rządów przez Fidela Castro oraz jego ludzi. Rewolucja kubańska i jej bohaterowie na trwałe włączyli się w codzienne życie mieszkańców wyspy. Plakat 1 ukazuje, oprócz nieśmiertelnego hasła Todo por la revolución (Wszystko dla rewolucji), także twarze czołowych postaci tych czasów, mianowicie Julio Antonio Melli (założyciel Komunistycznej Partii Kuby), Ernesto Che Guevary i Camilo Cienfuegosa (kubański rewolucjonista). Postery przedstawiające bohaterów rewolucji są niejako wrośnięte w tkankę miejska, stanowią niemalże "naturalne wypełnienie" pustej powierzchni tworząc typowe tło dla przestrzeni publicznej $\mathrm{w}$ ramach każdego totalitarnego państwa. Poster przypomina nieco „znak firmowy” rewolucji, która doczekała się nie tylko swoich bohaterów, lecz także symboli graficznych, kolorów i czcionek. Jedną z twarzy, która po latach stała się wręcz synonimem nie tylko tej rewolucji, lecz wielu innych masowych sprzeciwów wobec dominującej władzy, jest podobizna argentyńskiego rewolucjonisty Ernesto "Che" Guevary. Plakat 3, podobnie jak setki innych, przedstawia "Che", jak zawsze, w mundurze polowym, z nieodłącznym beretem na głowie. Napis na dole posteru venceremos (zwyciężymy), jak również oblicze legendy rewolucji zwrócone ku górze, bezsprzecznie utwierdzają oglądającego w przekonaniu, że wiara w powodzenie przedsięwzięcia graniczy z pewnością. Podobnie jak przy poprzednim plakacie, wykorzystana została tu fotografia, która tym bardziej uprawdopodabnia przesłanie posteru. Wykorzystanie zdjęć na plakatach stanowi swego rodzaju zabieg „odplakatowienia” treści plakatu. Poster, który prawie zawsze "naciąga rzeczywistość”, prezentuje ją w skrajnie jaskrawych, groteskowych kolorach, tym razem zadowala się "faktem”, który wiąże się z umieszczonym na nim zdjęciem. Jak zaznacza Kamila Biskupska (2011: 144) „Konsekwentne wykorzystywanie $\mathrm{w}$ plakatach fotografii czarno-białych związane było z położeniem akcentu na ich prawdziwość i postulowanym odbiorem na serio". Realny jest wyraz twarzy, mimika, spojrzenie, zmarszczki i zarost, co buduje 
przekonanie o wiernym odzwierciedleniu nie tego, co być może się dzieje lub stanie w nieodległej przyszłości, lecz o zapisie stanu obecnego w sposób kronikarski.

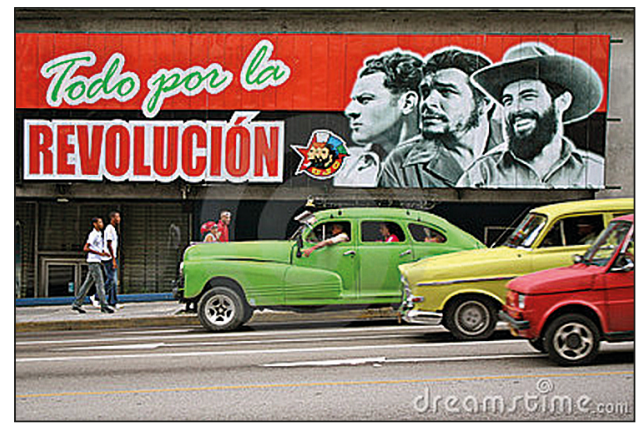

Plakat 1

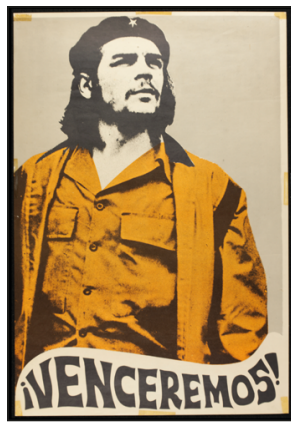

Plakat 2

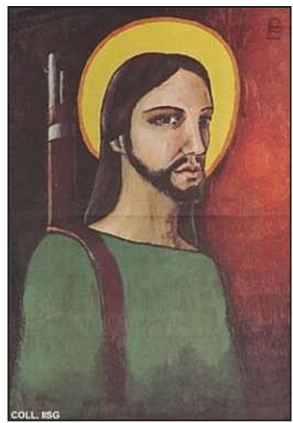

Plakat 3

Krystalizująca się na Kubie władza, podobnie jak każda inna nowa siła militarno-polityczna, potrzebowała symboli, które uwiarygadniałyby działania rewolucyjne jako walkę o słuszną sprawę, gdzie rację stanu wiązano by z filozofią marksistowską i nacjonalizacją gospodarki. Taką funkcję bezspornie spełnia plakat 3, przedstawiający sylwetkę Jezusa Chrystusa z twarzą księdza Camilo Torresa, który w ramach głoszonej przez siebie liberalnej teologii próbował powiązać marksizm z katolicyzmem, walcząc po stronie guerrillas w Kolumbii. Sylwetka księdza była wykorzystywana przez obóz Castro, który w okresie porewolucyjnym pragnął zjednać społeczne poparcie dla swoich reform, bliskich założeniom ruchu guerrillas. Zgoła inny jest wydźwięk plakatu 4, który stara się oddać dynamikę i dramatyzm walki. Przedstawia on, z jednej strony, scenkę rodzajową odnoszącą się do pola bitwy, a właściwie linii frontu, z drugiej zaś bohatera rewolucji w osobie Fidela Castro. Przywódca trzyma broń, lecz nie jest ona wymierzona w kogokolwiek, co może sugerować, że wynik starcia został już przesądzony, a bitwa ostatecznie wygrana. W prawym górnym rogu można rozpoznać twarz argentyńskiego eseisty i powieściopisarza Julio Cortázara, który - choć nie otwarcie - sympatyzował z rewolucjonistami, a któremu prace literackie Ernesto Che Guevary nie były obce (Standish, 2001: 121-122). Ukazana na plakacie jego postać nasuwa skojarzenie z proroctwem dotyczącym losów rewolucji jej wygrana została przez artystę przewidziana. Innym symbolem rewolucji jest umieszczona w tle plakatu podobizna jachtu Granma, w roku 1956 zakupionego przez członków Ruchu 26 lipca i użytego do transportu 82 rewolucjonistów, z których na skutek kontrataku wojsk Batisty przeżyło jedynie dwunastu, w tym Raul i Fidel Castro oraz Che Guevara. Treść, jak również 
kolorystyka plakatu (czerwień, brąz) podkreślają zaciekłość walk i zdecydowaną postawę obydwu stron. Pierwsza data umieszczona na plakacie to rok 1952 (druga data to rok końca rewolucji, przyp. autor), czyli odniesienie do okresu rządów Batisty i przygotowań do jego obalenia, których kluczowym punktem był nieudany atak na koszary Montcada w Santiago - 26 lipca 1953 r. Ostatni etap walk i zwycięstwo osiągnięte przez siły rewolucyjne przedstawia plakat 5 wydany z okazji 10. rocznicy rewolucji. Na pierwszym planie, pośród bezimiennych twarzy ludzi fetujących zwycięstwo, widoczna jest sylwetka Fidela Castro. Poster przekonuje, że bohater brał bezpośredni, czynny udział w rewolucji, a jej wynik stanowi konsekwencję zaangażowania $\mathrm{w}$ tę walkę. To nasuwa porównania z generałem Batista, który przewodził siłom rządowym zza biurka, nie narażając się w bezpośrednich starciach.

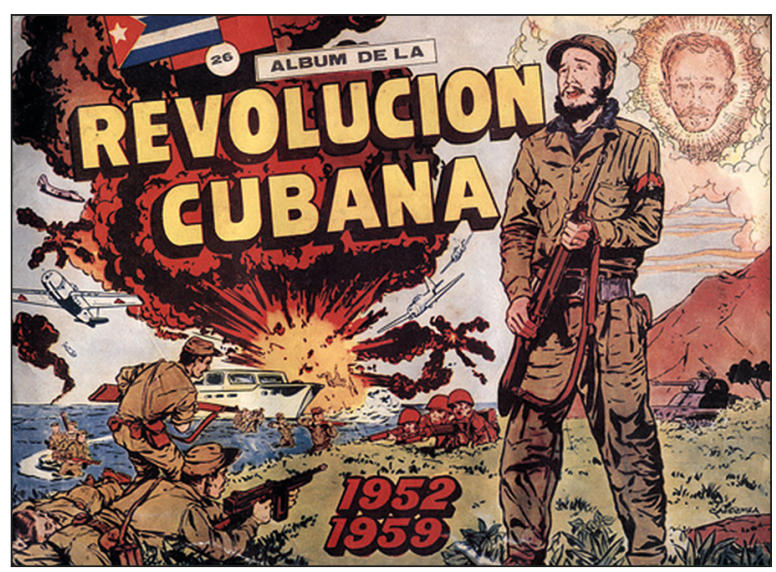

Plakat 4

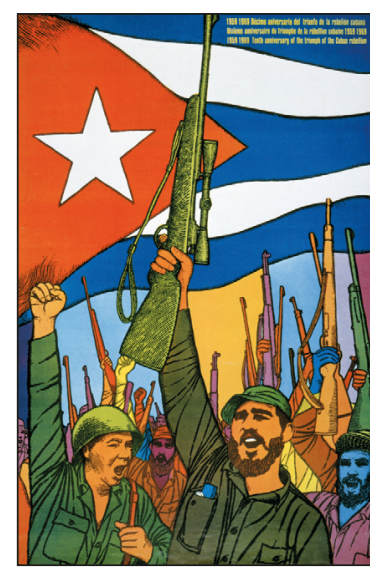

Plakat 5

\section{Armia rewolucyjna}

Każda propaganda, która podkreśla militarny aspekt zwycięstwa, kreuje także bohatera kolektywnego w postaci armii. Wojsko może być prezentowane jako bezimienna masa na tle przywódcy (plakat 5), lecz może także mieć twarz żołnierza lub przybrać postać oręża (por. Chomczyński 2011: 100). Ten ostatni motyw ucieleśnił się na plakatach kubańskich w dwóch formach, w zależności od tego, kto był wrogiem. W przypadku posterów ukazujących wojnę domową i walki bratobójcze (plakaty 4 i 5) armia rewolucyjna jest przedstawiana pod postacią żołnierzy, którzy współwystępują z atrybutami militarnymi (broń palna, umundurowanie, hełmy itd.). Zupełnie inaczej ma się sytuacja, gdy wrogiem są Stany 
Zjednoczone. Tutaj można wyodrębnić dwa zasadnicze trendy. Pierwszy z nich uwypukla dobrze uzbrojoną i zdeterminowaną armię kubańską gotową odeprzeć wroga, który wykorzystuje zaawansowany technologicznie sprzęt wojenny (plakaty 6 i 7). Plakat 6 przedstawia „las” karabinów, który układa się w coś na kształt zbrojnej bramy lub muru broniącego dostępu najeźdźcom. Napis Ante la provocacion firmes en bastion (Przed prowokacja pewni w bastionie - twierdzy) dodatkowo umacnia poczucie bezpieczeństwa i zaufania pokładane $\mathrm{w}$ armii kubańskiej. $\mathrm{W}$ innym klimacie utrzymany jest plakat 7. Ukazuje on dysproporcję sił na korzyść wroga, który dysponuje nowoczesną bronią. Przewaga technologiczna nie jest jednak w stanie zrównoważyć natarcia sił kubańskich, które w trakcie „zapomnianej wojny" (la guerra olvidada) z powodzeniem przeciwstawiły się inspirowanej przez Stany Zjednoczone inwazji w Zatoce Świń. Wspomagany przez północnego sąsiada zamach, mimo wykorzystania przez niego nowoczesnych środków militarnych, zakończył się fiaskiem. Ludzkie oblicze armii kubańskiej znalazło swój wyraz na kolejnym plakacie (plakat 8). Przedstawia on młodego mężczyznę wspartego na swoim karabinie, po trudach wojennych. Na jego twarzy widać zmęczenie. Podpis w trzech językach sugeruje rolę jego i podobnych mu żołnierzy - obywateli kubańskich, którzy przejęci losami Ameryki Łacińskiej walczą o jej niezależność (w domyśle od Stanów Zjednoczonych). Młodzieniec realizuje niełatwy obowiązek toczenia krwawego boju (czerwona łuna w tle) o słuszną sprawę. Swym wizerunkiem nadaje on kubańskiej armii charakter wyzwoleńczy, ludzki, humanitarny, co wzmaga ciepłe uczucia wobec niej. Te trzy plakaty można ulokować na swego rodzaju kontinuum, gdzie u jednego krańca dominuje bezosobowy, profesjonalny charakter, przechodzący poprzez podziw dla determinacji do sympatii zmieszanej ze współczuciem.

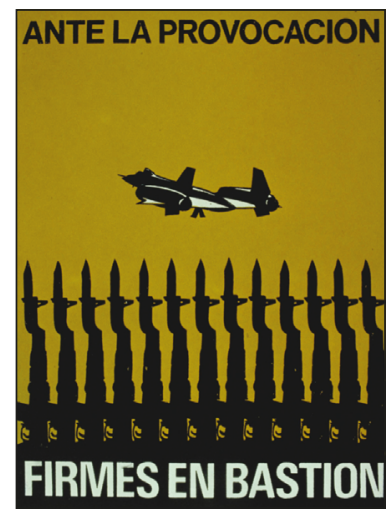

Plakat 6

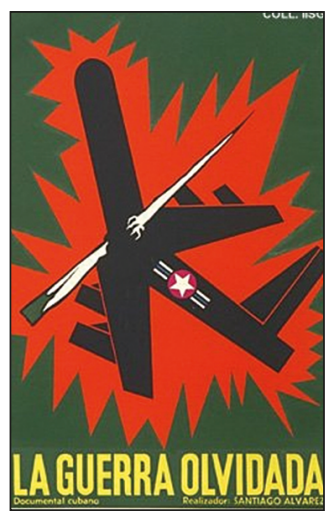

Plakat 7

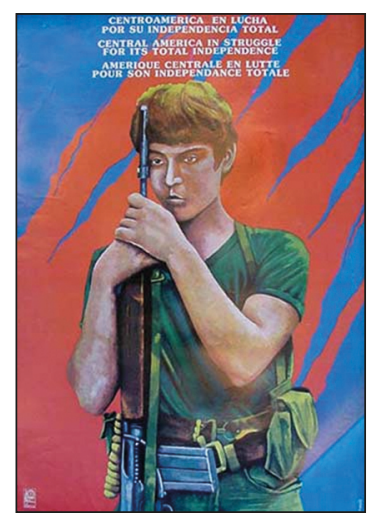

Plakat 8 


\section{Stany Zjednoczone jako pokonany wróg}

Proces stabilizacji władzy Fidela Castro i jego popleczników to okres burzliwych walk toczonych w ramach wojny domowej, a później z wrogiem zewnętrznym. Propaganda wymagała odniesienia do obydwu zagrożeń, choć stała przewaga wroga zewnętrznego wymogła na plakacistach wyraźną tendencję. Stany Zjednoczone zaczęły uosabiać wroga w ogóle, który ucieleśnia zagrożenia natury nie tylko wojennej, lecz także ustrojowej czy nawet cywilizacyjnej. Należy pamiętać o fakcie zbliżenia Kuby ze Związkiem Radzieckim, czego konsekwencją było jednoznaczne opowiedzenie się $\mathrm{w}$ globalnym sporze ideologicznym po stronie bloku komunistycznego. $W$ okresie zimnowojennym było to równoznaczne z zajęciem pozycji za żelazną kurtyną, w imię solidarności z państwami Układu Warszawskiego. Dalsze wydarzenia, w postaci kryzysu kubańskiego, przypieczętowały wcześniejsze podziały, polaryzując je aż do granic możliwości. W tym kontekście geopolitycznym zaobserwować można emisję plakatów, które odzwierciedlały ówczesne nastroje klasy rządzącej wobec północnego sąsiada. Na plakacie 9 widzimy tonącą w wodzie amerykańską flagę państwową. Jeśli powiążemy obraz z napisem $X$ aniversario de la victoria de Playa Giron (X rocznica zwycięstwa w Zatoce Świń) dochodzimy do wniosku, że prawdopodobnie poster przedstawia nieudaną inwazję na Kubę emigrantów wspieranych przez rząd Stanów Zjednoczonych, zepchniętych z powrotem do Morza Karaibskiego. Kształt i umiejscowienie flagi (przy pomina komin statku, okrętu) symbolizuje operację morska, która zakończyła się niepowodzeniem (widoczny jest dym, płomienie). Kolejny plakat znacznie silniej uderza w symbolikę Stanów. Widzimy na nim Wuja Sama rażonego piorunem, który powoduje dekapitację. Postać, doskonale znana z plakatów rekrutacyjnych wykorzystywanych do pozyskiwania ochotników do udziału w II wojnie światowej, traci swą siłę argumentacji na skutek interwencji boskiej. Piorun, jako nieodłączny emblemat mocy wyższej, wymierza sprawiedliwość. Jest ona efektem międzynarodowej solidarności z Kubą o czym świadczy czterojęzyczny napis Solidaridad mundial con la revolucion Cubana (Światowa solidarność z rewolucja kubańska). Motyw solidarności światowej wymierzonej przeciwko Stanom jest dość popularnym wątkiem widocznym na wielu kubańskich plakatach (patrz dalej). 


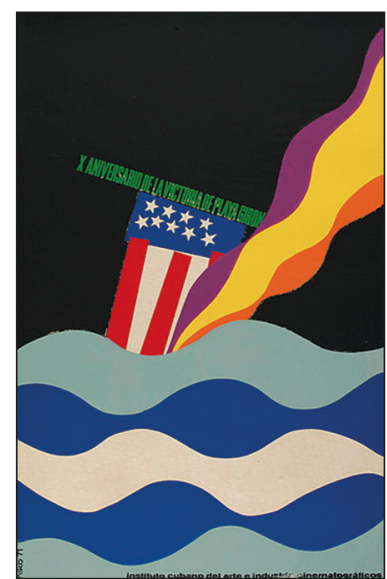

Plakat 9

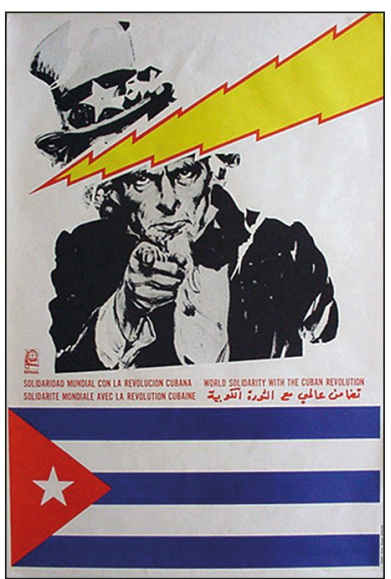

Plakat 10

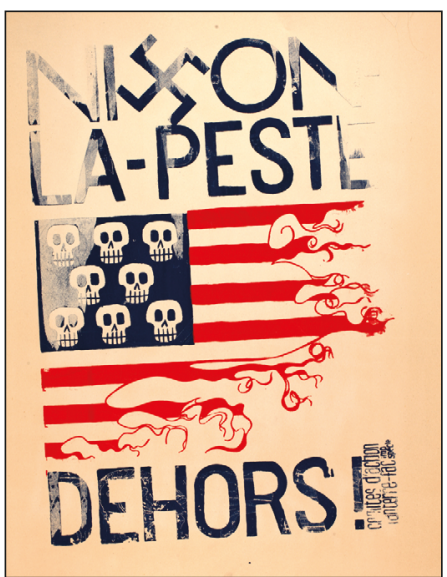

Plakat 11

Kolejny plakat (11) ma o wiele bardziej spersonalizowany charakter, gdyż dotyczy amerykańskiego prezydenta Richarda Nixona. Zastąpił on na tym stanowisku Johna F. Kennedy'ego, którego administracja stała za nieudaną inwazją w Zatoce Świń i zamachami na życie kubańskiego dyktatora (Nixon piastował wtedy urząd wiceprezydenta). W nazwisku Nixona dostrzec możemy swastykę, symbol faszystowskiej III Rzeszy, co niesie skojarzenia, że istnieje wspólny mianownik pomiędzy amerykańskim prezydentem i Adolfem Hitlerem. Sugestia ta jest dodatkowo wzmocniona wizerunkiem trupich czaszek (symbol między innymi ${ }^{10}$ zbrodniczej formacji SS). Być może plakaciści starali się $\mathrm{w}$ ten sposób wykazać podobieństwo metod stosowanych przez Nixona i jego administrację wobec Kuby i innych państw do taktyki hitlerowców. Dodatkowo wyrazu przydają posterowi słowa La pestedehors! które można przetłumaczyć jako zaraza (plaga) z zewnątrz. Konotacje tego zwrotu są dość jednoznaczne, zaraza sieje zniszczenie oraz śmierć, z którymi to zjawiskami utożsamiana jest prezydentura Nixona.

\section{Polityka zagraniczna Stanów Zjednoczonych}

Wysiłki propagandy kubańskiej zmierzały w kierunku umiędzynarodowienia konfliktu Kuby i Stanów Zjednoczonych. Przykładem takich działań były motywy uwidaczniane także na plakatach, gdzie starano się

${ }^{10}$ Na przestrzeni dziejów wiele formacji militarnych przyozdabiało swe mundury, sztandary, czapki wizerunkiem trupich główek. W tym jednak kontekście, gdy współwystępują one ze swastyka, skojarzenia z niemieckimi Totenkopf są jednoznaczne. 
przedstawić pejoratywnie amerykańską politykę zagraniczną. Jej twórców oskarżano o imperializm wyrażający się w strategii mającej na celu zniewolenie innych państw w imię korzyści materialnych (ropa, surowce mineralne, przyczółki strategiczne, itd.). Jednym z narzędzi dominacji Stanów nad innymi krajami była blokada ekonomiczna, która spychała gospodarkę takiego państwa do „cywilizacyjnego regresu”. Plakat 12 ukazuje ekonomiczny wymiar izolacji Kuby. Znowu mamy do czynienia z symboliką Stanów zmaterializowaną w postaci kapelusza Wuja Sama (patrz plakat 10), spod którego „wysypują się" napisy: „dewizy”, "ropa”, "leki”, ,eksport i import" opisujące główne wymiary międzynarodowej wymiany gospodarczej. Stanowią one jednolity przekaz wraz z tytułem posteru iNo al bloqueoeconómico a Cuba! (Nie dla blokady ekonomicznej Kuby!). Na kolejnym plakacie widzimy legendarnego konia trojańskiego, który symbolizuje skryta zdradę i działania niehonorowe. Figura ma barwy amerykańskie, co pozwala podstęp przypisać sąsiadowi z Północy. Na górze posteru widnieje napis: „Ten kto plądruje innych zawsze żyje w terrorze”, który stanowić ma pewien drogowskaz moralny, prawidłowość możliwą do zaobserwowania w wewnętrznych strukturach państwa stosującego politykę grabieżczą. Wątek amerykańskiego ekspansjonizmu wybitnie podkreśla plakat 14, który ukazuje amerykańskiego orła z twarzą Richarda Nixona. Ptak jest przedstawiony w trakcie polowania, a zdobyczą jest terytorium Laosu i Kambodży. Data emisji posteru (rok 1971) wskazuje, że przypada ona na okres eskalacji wojny w Wietnamie, gdy bombardowane były przez wojska amerykańskie także kraje ościenne, $\mathrm{w}$ tym wypadku stanowiące krwawą zdobycz trzymaną w szponach orła.

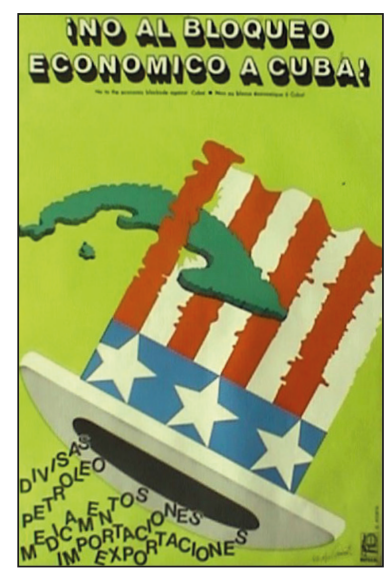

Plakat 12

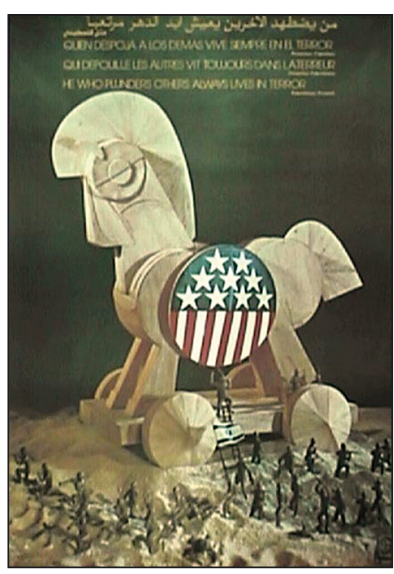

Plakat 13

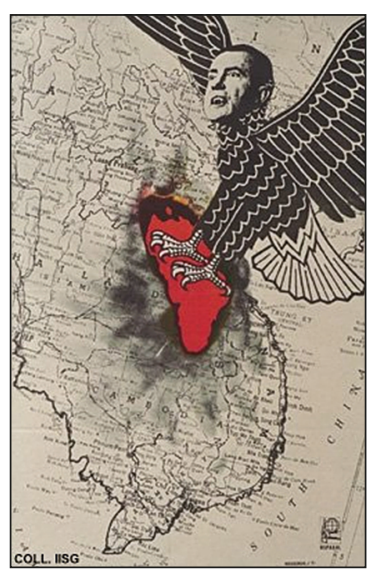

Plakat 14 
Motyw orła był dość często wykorzystywany w kubańskiej propagandzie antyamerykańskiej. Plakaty 15 i 16 ukazują krwawą ingerencję Stanów (jankesów) w Nikaragui. Na pierwszym z posterów ptak ma rozpostarte skrzydła (tak jak na plakacie 14), co sugeruje moment ataku. Ludzkie postacie umiejscowione $\mathrm{w}$ dole przypominają farmerów odstraszających ptaki sponad pól uprawnych lub polujące na drobną zwierzynę hodowlaną. Napis na plakacie: „Stop jankeskim atakom na Nikaraguę" dodatkowo wzmacnia defensywny wydźwięk przekazu. Role agresora i obrońców są klarowne. Złudzeń nie pozostawia także kolejny plakat $\mathrm{z}$ tej serii, gdzie agresor tym razem zyskuje nazwę. Jest to Centralna Agencja Wywiadowcza (Central Intelligency Agency - CIA) bezpośrednio odpowiedzialna za przygotowywanie i wdrażanie interwencji na terytorium innych państw. W tym przypadku także pojawia się orzeł będący, oprócz symbolu narodowego, także elementem symboliki CIA. W centralnej części widnieje zaciśnięta pięść, która przebiła się przez emblemat agencji. Odzwierciedla ona opór zaatakowanego państwa, dodatkowo podkreślony napisem: „Jedność w obliczu imperialistycznej agresji przeciwko Nikaragui". Przekaz posteru jest jasny - tylko zjednoczona siła (międzynarodowa) jest w stanie przeciwstawić się Stanom. Kuba, na której znajdowała się siedziba organizacji OSPAAAL, przyjęła na siebie przewodnią rolę $\mathrm{w}$ organizacji symbolicznego międzynarodowego oporu wobec sąsiada z Północy. Jeszcze bardziej zdecydowany jest wydźwięk kolejnego plakatu, gdzie po środku widzimy odwróconą tyłem postać, trzymającą w ręku nóż oznaczony symbolami Stanów Zjednoczonych, a w szczególności przedstawianej już wcześniej CIA. Narzędzie zbrodni, jak również pokazany chwyt, przywodzi na myśl działania skrytobójcze, których kwintesencją jest nagły atak na ofiarę, gdy ta niczego się nie spodziewa. Agresor jest ubrany w garnitur, spod rękawa którego wysuwa się mankiet w państwowych kolorach amerykańskich, co rodzi skojarzenia z amerykańską klasą polityczną lub decydentami agencji rządowych, odpowiedzialnych za zamachy i przewroty polityczne. Zamiłowanie kubańskich plakacistów do umieszczania na posterach prezydentów USA pozwala przypuszczać, że skrytobójca jest sam przywódca. Taka sugestia znajduje odzwierciedlenie w pytaniu: „Kto zamordował liderów trzeciego świata?”

Plakaty należące do tej kategorii jednoznacznie czynią rząd amerykański adresatem oskarżeń o ekspansjonizm i imperializm realizowany za pomocą „,brudnych metod”. Działania skrytobójcze (plakat 17), niehonorowe, oparte na podstępie (plakat 13) i niepohamowanej agresji (plakat 14) zyskują konkretną twarz przywódców narodu. Taki zabieg pozwala personifikować zło, które traci charakter abstrakcyjny na „korzyść” konkretnej osoby, do której łatwiej jest kierować zbiorową nienawiść i rządzę zemsty. 


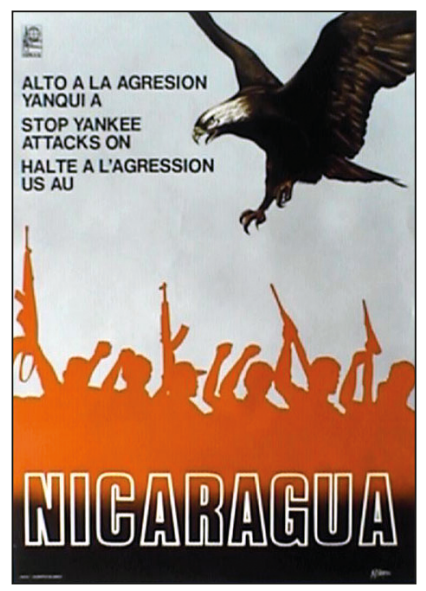

Plakat 15

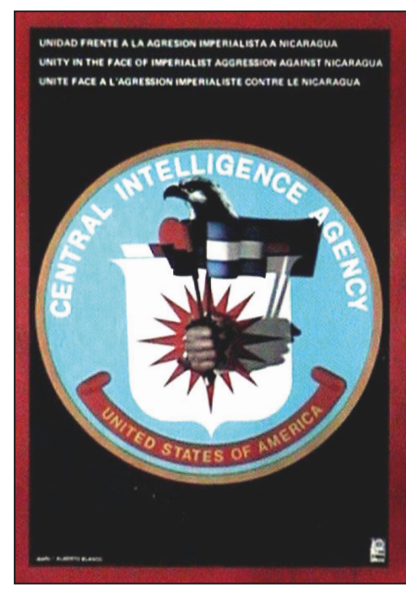

Plakat 16

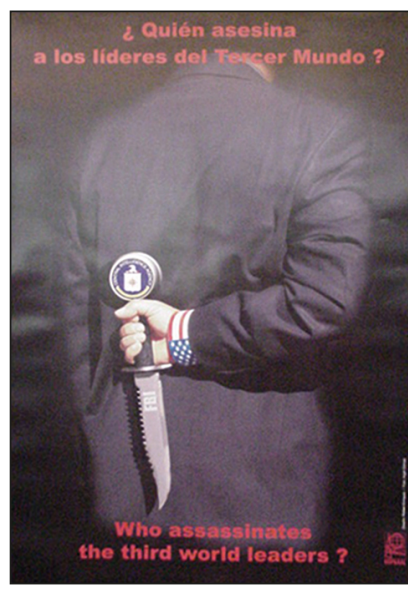

Plakat 17

\section{Międzynarodowa solidarność przeciwko Stanom Zjednoczonym}

Konsekwencją propagandy kubańskiej, mającej na celu wykazanie agresji i imperializmu leżących u podstaw amerykańskiej polityki wobec innych krajów, było przyjęcie na siebie roli orędownika międzynarodowej solidarności zwróconej przeciwko Stanom Zjednoczonym. Władze kubańskie, na skutek sterowanych przez Amerykanów nieudanych interwencji w wewnętrzne sprawy wyspy (inwazja w Zatoce Świń, nieudane zamachy na Fidela Castro), przypisały sobie moralne przewodnictwo $\mathrm{w}$ budowaniu międzypaństwowego sojuszu wymierzonego w Stany. Z pewnością inicjatywa ta była popierana przez Związek Radziecki i pozostałe państwa demokracji ludowej. Dla urzeczywistnienia tej propagandy nieodzowny okazał się wielokrotnie wspominany OSPAAAL, którego symbole widnieją na większości plakatów wzywających do solidarności. Plakat 18 bezsprzecznie przedstawia wyraz tych tendencji (napis: „światowa solidarność z Kubą). Amerykańska agresja pod postacią wymierzonego w Kubę rewolweru zwraca się przeciwko agresorowi. Wygięta lufa rewolweru, stanowiąca zagrożenie dla strzelca, nie dla jego celu, rodzi skojarzenie z porzekadłem wyrażającym ludową sprawiedliwość „kto mieczem wojuje, od miecza ginie".

Szerszy aspekt solidarności wymierzonej przeciwko Stanom podnosi kolejny plakat, gdzie do walki podrywa się cały południowoamerykański 
kontynent. Zaciska się on w formie dłoni wokół strzelby, co narzuca skojarzenia z powstaniem. Zazwyczaj powstania były wzniecane przeciwko "złej” (narzuconej z zewnątrz) władzy. Napis na dole „międzynarodowy tydzień solidarności z Ameryką Łacińską" (International week of solidarity with Latin America) daje podstawy do postrzegania tego kontynentu jako ofiary, która postanawia rozerwać łańcuch poddaństwa. Choć nie jest to wyrażane wprost, adresatem międzynarodowego zrywu są oczywiście Stany Zjednoczone. Apele o jedność państw socjalistycznych znalazły posłuch także w krajach demokracji ludowej oddalonych od Kuby o tysiące kilometrów. Plakat 20, autorstwa czechosłowackich artystów, przedstawia wśród rewolucjonistów także sylwetkę Fidela Castro, który tym samym został włączony w panteon przeciwników Ameryki.

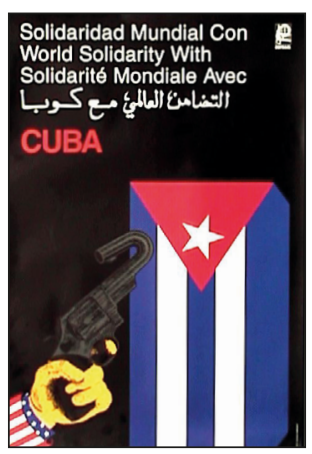

Plakat 18

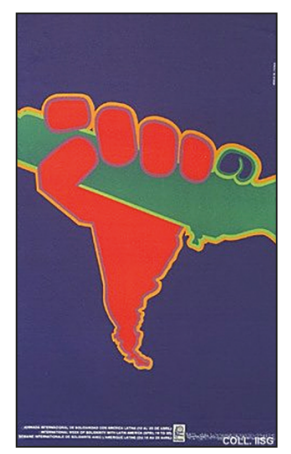

Plakat 19

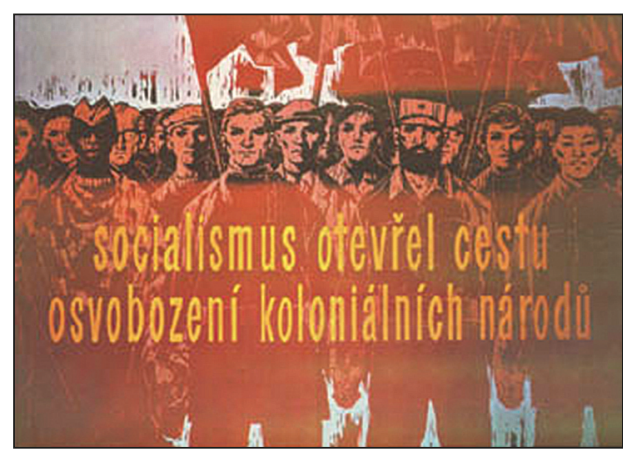

Plakat 20

\section{Kapitalizm i zagrożenia z nim związane}

W gronie kubańskich plakatów propagandowych poczesne miejsce zajmują te, które odnoszą się do systemu kapitalistycznego oraz związanych z nim niebezpieczeństw. Liberalizm gospodarczy jest przedstawiany w kategoriach wielkiego zagrożenia, które przybiera formę starcia cywilizacyjnego. Waga problemu usprawiedliwia użycie wartości religijnych i uniwersalnych symboli postępów ludzkości. Plakat 21 jest bardzo silny w swoim przekazie, gdyż dotyczy jednego z najbardziej świętych symboli religijnych, mianowicie Jezusa Chrystusa, w tym przypadku zamiast na krzyżu umieszczonego na dolarze amerykańskim, który tym samym zyskuje wymiar narzędzia zbrodni. Zamiast słowa Inri umieszczony jest tu symbol FMI (Fondo Monetario Internacional) oznaczający Międzynarodowy 
Fundusz Walutowy (International Monetary Fund). Martyrologia Chrystusa zyskała nowy wymiar i przyczynę, tym razem ekonomiczna, związaną z dominacją gospodarczą Stanów. Autorzy plakatu przekonuja, że jest ona źródłem cierpienia i grzechu. Napis na dole o treści: "dług zagraniczny” wyjaśnia intencje plakatu do końca, nie pozostawiając żadnych wątpliwości. Uzależnienie ekonomiczne innych krajów od Stanów jest przyczyną ich wyzysku i cierpień. W nieco podobnej konwencji utrzymany jest także plakat 22, który w sposób groteskowy przedstawia pamiętne dzieło Leonarda da Vinci. W tym wypadku postać człowieka jest zniewolona łańcuchami, nad nią unosi się zaś sylwetka orła symbolizującego Stany Zjednoczone. Podpis pod plakatem: „Kapitalizm: zaprzeczenie praw człowieka” nie pozostawia złudzeń, kto jest ofiarą liberalizmu gospodarczego. Dodatkowy opis cierpień wpisanych w ustrój kapitalistyczny znaleźć można w słowach okalających sylwetkę człowieka autorstwa da Vinci: "głód, regres, bezrobocie, rasizm". W przekonaniu plakacistów stanowią one kwintesencję liberalizmu gospodarczego utożsamianego ze Stanami.

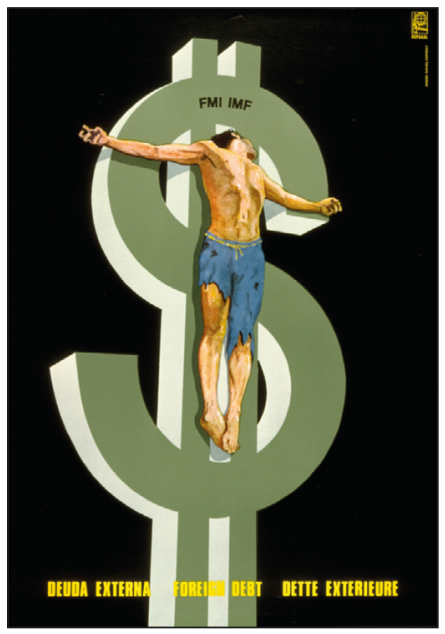

Plakat 21

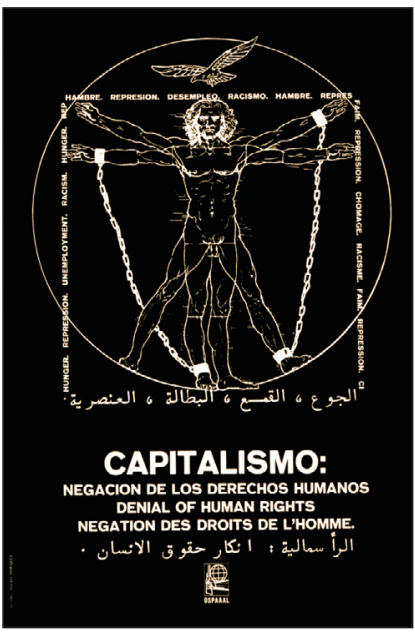

Plakat 22

\section{Podsumowanie i zakończenie}

Kubańska propaganda plakatowa obejmuje wiele obszarów, takich jak gospodarka wewnętrzna i światowa, sprawy społeczne, prawa człowieka, polityka zagraniczna oraz wewnętrzna. Można jednak dostrzec 
pewną tendencję, mianowicie na każdym z tych obszarów w mniejszym bądź większym stopniu odciśnięty jest wizerunek Stanów Zjednoczonych, które raz przyjmują postać agresora, innym razem jedynie zagrożenia lub zmaterializowanego zła wyrażającego się w negatywnych postawach i normach (chciwość, skłonność do przemocy, zachłanność i inne). Wiele $\mathrm{z}$ treści posterów zawiera $\mathrm{w}$ sobie zaprzeczenie tych pejoratywnych rządz, przeciwstawiając im ład aksjonormatywny typowy dla społeczeństwa kubańskiego. Warto tutaj nadmienić, że plakaty kubańskie różnią się w swej treści i formie od euroamerykańskich. Kubańskie postery, poza nielicznymi wyjątkami, są bardziej wysublimowane, abstrakcyjne, mniej dosłowne, większe znaczenie odgrywa tu kolor i kompozycja, które niosą za sobą skojarzenia "baśniowe” apologizujące niemalże mityczne czyny przeszłych i obecnych bohaterów.

Tożsamość polityczna i światopoglądowa Kuby rodzi się z negacji wartości składających się na system ustrojowy USA. Biegun podziału na „dobrych" i „złych" ma płaszczyznę prawnopolityczna, gdzie myśl socjalistyczną przeciwstawia się kapitalistycznej. Warto zauważyć, że Kuba jest "symbolicznym” reprezentantem także i innych państw Ameryki Łacińskiej, u których dostrzec można socjalistyczne inklinacje (określane jako „różowa fala”), stanowiące w pewnej mierze konsekwencję polityki Stanów Zjednoczonych, mniej lub bardziej bezpośrednio wspierających środowiska prawicowe. Cieszący się przychylnością krajowej opinii publicznej przywódcy Ameryki Południowej wprowadzają reformy typowe dla ustrojów socjalistycznych (nacjonalizacja, etatyzm państwowy, centralne planowanie). Chugo Chávez głosił w Wenezueli „Socjalizm XXI wie$\mathrm{ku}^{\prime \prime}, \mathrm{w}$ polityce wewnętrznej prezydenta Ekwadoru Rafaela Correa także widoczne są silne tendencje socjalistyczne, podobnie jak u Evo Moralesa Eyma (Boliwia) i Daniela Ortegi (Nikaragua).

Choć od przełomowych wydarzeń, takich jak rewolucja kubańska, interwencja w Zatoce Świń, kryzys rakietowy oraz kolejne próby zamachu na Fidela Castro minęło już ponad pół wieku, to jednak propaganda wciąż jest intensywna i żywa, widoczna w codziennym życiu, stanowiąc wszechogarniającą rzeczywistość. Kuba wydaje się krajem, gdzie czas się w pewnym momencie zatrzymał. Przypominają o tym nie tylko wszechobecne postery i podobizny bohaterów rewolucji, lecz także stare samochody, architektura i zwyczaje ukształtowane przed półwieczem. 
¡Viva la Revolución! Rewolucja kubańska 1956-1959...

\section{Bibliografia}

Biskupska, K., (2011), Analiza dyskursywna amerykańskich plakatów rekrutacyjnych okresu II wojny światowej, [w:] Socjologia wizualna w praktyce. Plakat jako narzędzie propagandy wojennej, red. T. Ferenc, W. Dymarczyk, P. Chomczyński. Łódź: Wydawnictwo Uniwersytetu Łódzkiego.

Chomczyński, P., (2011) „Wielka wojna ojczyźniana" na plakatach sowieckich, [w:] Socjologia wizualna w praktyce. Plakat jako narzędzie propagandy wojennej, red. T. Ferenc, W. Dymarczyk, P. Chomczyński. Łódź: Wydawnictwo Uniwersytetu Łódzkiego.

Chomczyński, P., (2012), Atlas TI, [w:] Słownik socjologii jakościowej. Warszawa: Wydawnictwo Difin SA.

Dymarczyk, W., (2011), "Hej! Kto Polak na bagnety” kontra "Obronimy zdobycze Października”. Polskie i radzieckie plakaty wojenne - próba zrozumienia, [w:] Socjologia wizualna w praktyce. Plakat jako narzędzie propagandy wojennej, red. T. Ferenc, W. Dymarczyk, P. Chomczyński. Łódź: Wydawnictwo Uniwersytetu Łódzkiego.

Ferenc, T., (2007), Analiza obrazów - przeglad metod i inspiracji teoretycznych, „Acta Universitatis Lodziensis", Folia Sociologica 32, s. 5-26.

Ferenc, T., (2011), Bohater, wróg, zdrajca - amerykańskie i niemieckie plakaty z okresu II wojny światowej, [w:] Socjologia wizualna w praktyce. Plakat jako narzędzie propagandy wojennej, red. T. Ferenc, W. Dymarczyk, P. Chomczyński. Łódź: Wydawnictwo Uniwersytetu Łódzkiego.

Frąckowiak, M., (2008), Zdjęcie jako rebus. Zastosowanie wywiadu fotograficznego na przykładzie badań „Pornografialerotyka: pytanie o kontekst czy estetykę?”, [w:] Do zobaczenia. Socjologia wizualna w praktyce badawczej, red. J. Kaczmarek. Poznań: Wydawnictwo Naukowe UAM.

Gadea, H., (2008), Rebel Wife. My Life with Che, The Making of a Revolutionary, „The Washington Post", 12 October.

Goffman, E., (1979), Gender Advertisements. New York-Hagerstown-San Francisco-London: Harper \& Row Publishers.

Hendrix, H., (1959), Executions Schock? Here's Castro's Side, Miami News, January 18 (http:// news.google.com/newspapers?nid=2206\&dat=19590118\&id=wa0yAAAAIBAJ\&sjid=K OwFAAAAIBAJ\&pg=1809,757516, dostęp z dnia 15 X 2012).

Konecki, K.T., (2005), Wizualne wyobrażenia. Główne strategie badawcze w socjologii wizualnej a metodologia teorii ugruntowanej, „Przegląd Socjologii Jakościowej”, vol. I, nr 1.

Konopásek, Z., (2008), Making Thinking Visible with Atlas.ti: Computer Assisted Qualitative Analysis as Textual Practices, „Forum Qualitative Sozialforschung/Forum: Qualitative Social Research", 9 (2), Art. 12 (http://www.qualitative-research.net/index.php/fqs/article/view/420/911, dostęp z dnia 16 X 2012).

Lippmann, W., (2006), Originality and Relevance of the Cuban Revolution, „Democracy and Revolution", ss. 77-131.

Luis, J.G., (2008), Cuban Revolution Reader. A Documentary History of Fidel Castro's Revolution. Melbourne-New York-London: Ocean Press.

Rose, G., (2006), Visual methodologies. London-Thousand Oaks-New Delhi: Sage Publications Inc.

Standish, P., (2001), Understandng Julio Cortázar. Columbia, South Carolina: University of South Carolina Press. 
Stańczak, G.G., (2007), Visual Research Methods. Image, Society and Represenations. Los Angeles-London-New Delhi-Singapore: Sage Publications Inc.

Strauss, A.L., Corbin, J., (1990), Basics of Qualitative Research. Grounded Theory. Procedures and Techniques. California: SAGE Publications.

\section{Strony internetowe:}

http://www.cuban-posters.freeservers.com/beltran.html http://www.docspopuli.org/CubaPosters.html http://www.freyafaulkner.blogspot.com/2011/02/cuban-revolutionary-posters-essay.html http://www.haciendapublishing.com/articles/fidel-castro-and-26th-july-movement http://www.historyofcuba.com/history/time/timetbl4.htm http://www.latinamericanstudies.org/cuba-1952-1956.htm http://www.ospaaal.com/index.html http://www.stosunkimiedzynarodowe.info/kraj_start.php?xkraj_stos=USA\&kraj=Kuba \&typ=stosunki+dwustronne

\section{Informacje na temat wykorzystanych w pracy plakatów}

\section{Rycina 1}

Flaga Ruchu 26 lipca

Źródło: http://everydaysaholiday.org/day-of-national-rebelliousness-cuba

\section{Rysunek 1}

Symbol organizacji OSPAAAL

Źródło: http://www.ospaaal.com/index.html

\section{Plakat 1}

Autor: nieznany

Tytuł: Todo por la Revolución (Wszystko dla rewolucji)

Źródło: http://thumbs.dreamstime.com/thumblarge_537/1284046682Q92J11.jpg

\section{Plakat 2}

Autor: nieznany, ok. roku 1970

Tytuł: ¡Venceremos! (We Shall Overcome!; Zwyciężymy)

Źródło: http://www.vam.ac.uk/content/articles/c/cold-war-revolution-and-protest

\section{Plakat 3}

Autor: Alfrédo Rostgaard, 1969

Tytuł: Christ guerrillero

Źródło: http://www.iisg.nl/exhibitions/chairman/cub19.php

\section{Plakat 4}

Autor: nieznany

Tytuł: Revolución Cubana

Źródło: http://thumbs.dreamstime.com/thumblarge_537/1284046682Q92J11.jpg 
¡Viva la Revolución! Rewolucja kubańska 1956-1959...

\section{Plakat 5}

Autor: nieznany

Tytuł: 1959-1969 Décimo aniversario del triunfo de la rebelión cubana

Źródło: http://vi.sualize.us/1959_1969_decimo_aniversario_del_triunfo_de_la_rebelion_ cubana_poster_propaganda_cuba_picture_Gbq.html

\section{Plakat 6}

Autor: nieznany

Tytuł: Firmes en bastion (Ante la provocacion firmes en bastion; Przed prowokacja pewni w bastionie - twierdzy)

Źródło: plakatu po pobraniu ze strony internetowej ponownie nie odnaleziono

\section{Plakat 7}

Autor: Alfredo Rostgaard, 1967

Wydawca: ICAIC

Tytul: The forgotten war (La guerra olvidada; Zapomniana wojna)

Źródło: http://www.iisg.nl/exhibitions/chairman/cub32.php

\section{Plakat 8}

Autor: Rafael Morante, 1985

Wydawca: OSPAAAL

Tytuł: Centroamérica en lucha por su independencia total

Źródło: http://www.ospaaal.com/latin.html

\section{Plakat 9}

Autor: Nico, 1971

Wydawca: Instituto Cubano del Arte e Industria

Tytuł: X Aniversario de la Victoria de Playa Giron (X rocznica zwycięstwa w Zatoce Świń)

Źródło: http://collections.vam.ac.uk/item/O113127/x-aniversario-de-la-victoria-poster-niko/

\section{Plakat 10}

Autor: Victor Manuel Navarrete, 1980

Wydawca: OSPAAAL

Tytuł: Solidaridad mundial con la revolucion Cubana (Światowa solidarność z rewolucja kubańska).

Źródło: http://www.ospaaal.com/latin3.html

\section{Plakat 11}

Autor: nieznany, ok. roku 1969

Tytuł: Nixon - La Pestedehors!

Źródło: http://www.vam.ac.uk/content/articles/c/cold-war-revolution-and-protest

\section{Plakat 12}

Autor: nieznany

Wydawca: OSPAAAL

Tytuł: ¡No al bloqueoeconómico a Cuba! (Nie dla blokady ekonomicznej Kuby!)

Źródło: http://cuban1.sweb.cz/big_cuban1/0046.jpg 


\section{Plakat 13}

Autor: nieznany

Wydawca: OSPAAAL

Tytul: He who plunders others always lives in terror (Ten, kto pladruje innych zawsze żyje w terrorze)

Źródło: http://cuban1.sweb.cz/big_cuban1/0047.jpg

\section{Plakat 14}

Autor: René Mederos, 1971

Wydawca: Publisher OSPAAAL

Tytuł: Nixon

Źródło: http://www.iisg.nl/exhibitions/chairman/cub24.php

\section{Plakat 15}

Autor: nieznany, 1985

Wydawca: OSPAAAL

Tytuł: Alto a la agresión yanqui a Nicaragua (Stop jankeskim atakom na Nikarague)

Źródło: http://thecahokian.blogspot.com/2010/07/anti-american-art-no-place-to-land.html

\section{Plakat 16}

Autor: nieznany

Wydawca: OSPAAAL

Tytuł: Unidad frente a la agresión imperialista a la Nicaragua (Jedność w obliczu imperialistycznej agresji przeciwko Nikaragui)

Zródło: http://cuban1.sweb.cz/big_cuban1/0125.jpg

\section{Plakat 17}

Autor: nieznany

Wydawca: OSPAAAL

Tytuł: ¿Quién asesina a los lideres del tercer mundo líderes? (Kto zamordował liderów trzeciego świata?)

Źródło: http://www.ospaaal.com/other7.html

\section{Plakat 18}

Autor: Rafael Enríquez, 1980

Wydawca: OSPAAAL

Tytuł: Solidaridad Mundial Con (Światowa solidarność z Kuba)

Źródło: http://cuban1.sweb.cz/big_cuban1/0045.jpg

\section{Plakat 19}

Autor: Asela Perez, 1970

Wydawca: OSPAAAL

Tytuł: International week of solidarity with Latin America (Międzynarodowy tydzień solidarności $z$ Ameryka Eacińska)

Źródło: http://www.iisg.nl/exhibitions/chairman/cub22.php 
¡Viva la Revolución! Rewolucja kubańska 1956-1959...

Plakat 20

Autor: nieznany

Tytuł: Socialismus otrevel cestu osvobodzeni kolonialnich narodu (Socjalizm otworzyt drogę do wyzwolenia ludów kolonialnych)

Źródło: plakatu po pobraniu ze strony internetowej ponownie nie odnaleziono

\section{Plakat 21}

Autor: Rafael Enríquez, 1983

Tytuł: FMI IMF

Źródło: http://www.ospaaal.com/other.html

\section{Plakat 22}

Autor: nieznany, wydrukowany przez Mercie Group, 2003

Wydawca: OSPAAAL

Tytuł: Capitalismo: negacion de los derechos humanos (Kapitalizm: zaprzeczenie praw człowieka)

Źródło: (http://www.politicalgraphics.org/cgi-bin/album.pl?photo=35masterpeaces\%2F515_ PG_23264.jpg) 